\title{
Carcinoid Tumor on Mature Cystic Ovarian Teratoma in A Young Woman
}

\author{
Salem Bouomrani ${ }^{1,2 *}$, Fatma Rekik ${ }^{1,2}$, Mouna Guermazi ${ }^{1,2}$ and Souad Yahyaoui ${ }^{1}$ \\ ${ }^{1}$ Department of Internal medicine, Military Hospital of Gabes, Gabes 6000. Tunisia \\ ${ }^{2}$ Sfax Faculty of Medicine. University of Sfax, Sfax 3029. Tunisia
}

Submission: February 04, 2019; Published: February 13, 2019

*Corresponding author: Salem Bouomrani, Department of Internal medicine, Military Hospital of Gabes, Gabes 6000. Tunisia

\begin{abstract}
Mature cystic teratoma (MCT) is a fairly common benign germ cell ovarian tumor but present a risk of malignant transformation estimated at $0.17-2 \%$. This malignant transformation occurs classically in the elderly and is mainly squamous cell carcinoma type. Carcinoid tumors occurring on MCT remain exceptional, unusual, and only a few sporadic cases are reported. We report an original observation of a carcinoid tumor arising from a MCT of the ovary in a 35-year-old woman.
\end{abstract}

Keywords: Mature cystic teratoma; Ovary; Carcinoid tumor; Malignant transformation; Young woman

\section{Introduction}

Mature cystic teratoma (MCT), also known as the dermoid cyst [1], is a fairly common germ cell ovarian tumor [1-3]. It accounts for 10 to $20 \%$ of all ovarian tumors [3-5], with an estimated incidence of 1.2-14.2/ 100,000 people per year [2,4].

These tumors are benign but present a risk of malignant transformation estimated at $0.17-2 \%$ [1-5]. This malignant transformation is mainly squamous cell carcinoma type $75 \%$ of cases) $[1,2,4,6,7]$; rarer are: a large spectrum of adenocarcinomas, papillary thyroid cancer, malignant melanoma, sarcomas, neuroectodermal tumors, and non-Hodgkin's lymphomas [3-7]. Carcinoid tumors occurring on MCT remain exceptional and not usual $[8,9]$.

The malignant transformation of ovarian MCT is typically seen in postmenopausal elderly women $[1,4-7,10]$; Its occurrence in young women remains exceptional [10]. We report an original observation of a carcinoid tumor arising from a MCT of the ovary in a 35-year-old woman.

\section{Case Report}

A 35-year-old woman, with no notable pathological antecedents, was admitted for exploration of an abdominopelvic swelling accidentally discovered on systematic examination. The somatic examination revealed on palpation the presence of an abdominal-pelvic mass, lateralized on the left and arriving at the umbilicus, which is well limited, of soft consistency, and painless.
The rest of the somatic examination was without abnormalities; In particular, no palpable peripheral lymphadenopathy or visceromegaly was noted.

Basic biological tests were within normal limits: total blood count, erythrocyte sedimentation rate, C-reactive protein, serum protein electrophoresis, fasting blood glucose, creatinine, serum calcium, ionogram, transaminases, muscle enzymes, and lipid parameters. Pelvic ultrasonography revealed the presence of a mixed-component, predominantly solid, left-lateral and retrouterine mass with small hyperechoic images suggestive of ovarian teratoma (Figure 1). Abdominal ultrasound was normal.

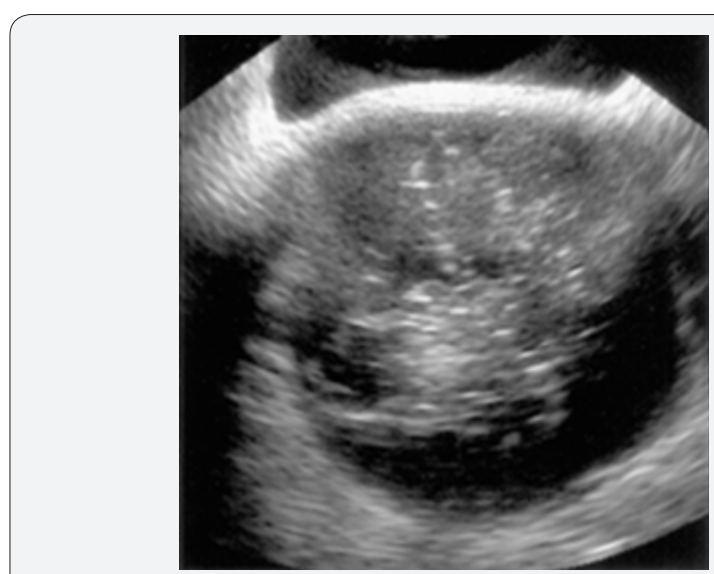

Figure 1: Pelvic ultrasonography showing a left lateral uterine tumor with a mixed component and small hyperechoic images. 
The exploratory laparotomy found a left ovary tumor, seat of a mass of $20 \mathrm{~cm}$ in diameter without exo-cystic vegetations and soft consistency. The right ovary, the two fallopian tubes, and the uterus were normal. Left oophorectomy was performed. Histological examination revealed a multi-tissue MCT, one component of which was intestinal and had a small carcinoid tumor (Figure 2\&3). The evolution was favorable and without recurrence after five years of surgery.

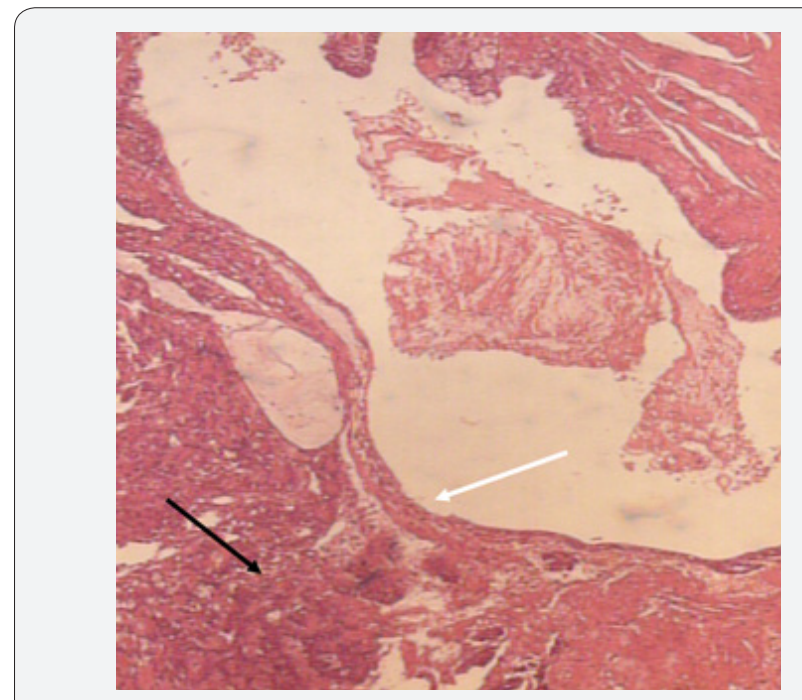

Figure 2: Histological slide, $\mathrm{HE} \times 40$ : cystic cavity lined by intestinal epithelium surrounded by smooth muscle (white arrow) with carcinoid tumor visible below and to the left (black arrow).

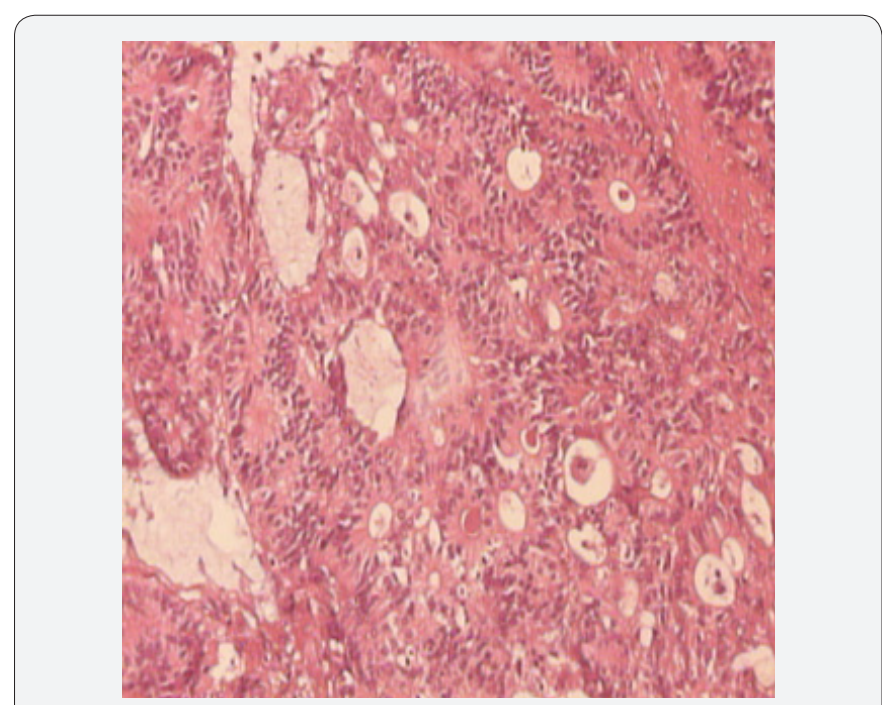

Figure 3: Histological slide, HE $\times 100$ : carcinoid tumor with multiple cell rosettes without atypia or mitosis.

\section{Discussion}

Malignant transformation of ovarian MCT remains rare [4-6] accounting for only $1.5 \%$ of all malignant ovarian tumors [4]. These changes usually occur in elderly women around the menopause and are exceptionally observed in young women $[1,4-7,10]$. The preoperative diagnosis of these transformations is often difficult
$[2,5,10]$ because these tumors remain asymptomatic for a long time; more rarely they can be diagnosed because of abdominal pain or a rapid increase in the volume of the abdomen $[4,10]$. Their diagnosis is usually made postoperatively and the confirmation is always histological on histopathological examination [2,5].

The treatment of choice is radical surgery with uni- or bilateral salpingo-oophorectomy with omentectomy $[2,4,10]$, sometimes associated with hysterectomy [2,4]. Adjuvant chemotherapy may sometimes be indicated, particularly in advanced stages $[1,2,7]$. Carcinoid tumors arising from ovarian MCT are exceptional and unusual $[8,9]$. The majority of cases are reported as sporadic observations [8,9,11-14]. Ovarian carcinoids represent $0.3 \%$ of all carcinoid tumors and less than $0.1 \%$ of ovarian cancers [9]. As a result, they are often unrecognized and under-diagnosed [12]. They are most often incidentally detected on the histological examination of the operative specimens $[9,11,12]$.

The carcinoids of the ovary are classified into four histological types: mucinous, trabecular, mixed, and insular types. The last type is the most common and is often associated with a carcinoid syndrome $[9,11,13,14]$. These ovarian carcinoids arising from MCT can be isolated or, more rarely, become part of a multiple endocrine neoplasia type I [15]. Like any other malignant transformation of ovarian MCT, carcinoid tumors typically occur in peri- or post-menopausal women [14] and remain exceptional and unusual in young women [13].

\section{Conclusion}

MCTs of ovaries are fairly common benign tumors of women. Their malignant transformation is rare, by far dominated by squamous cell carcinomas, and is observed around the menopause. Carcinoid tumors arising from ovarian MCT remain exceptional and unusual. Our observation is further characterized by its occurrence in young women of childbearing age.

\section{References}

1. Baum S, DiGregorio K, Alhassan R, Jormark S, Villella J, et al. (2019) Management options for a patient with squamous cell carcinoma arising in a mature cystic teratoma of the ovary. J Exp Ther Oncol 13(1): 45-48.

2. Gadducci A, Guerrieri ME, Cosio S (2019) Squamous cell carcinoma arising from mature cystic teratoma of the ovary: A challenging question for gynecologic oncologists. Crit Rev Oncol Hematol 133: 9298.

3. Cokmez H, Gulbahar A, Yigit S, Aydin C (2019) Oncocytic and tall columnar type papillary thyroid carcinoma arising on a mature cystic teratoma: A case report and literature review. J Pak Med Assoc 69(1): 116-119.

4. Maeda K, Terai Y, Terada S, Maruoka H, Kogata Y, et al. (2018) A case of ovarian clear cell carcinoma arising from ovarian mature cystic teratoma. J Ovarian Res 11(1): 74.

5. Afzal S, Zaman S (2017) High Grade B- Cell Non- Hodgkin's Lymphoma Arising in a Mature Cystic Teratoma of The Ovary: A Case Report. Int J Mol Cell Med 6(4): 239-242.

6. Rathore R, Sharma S, Agarwal S (2018) Malignant transformation in mature cystic teratoma of the ovary: a retrospective study of eight cases and review of literature. Prz Menopauzalny 17(2): 63-68. 
7. Wazzan AA, Popowich S, Dean E, Robinson C, Lotocki R, et al. (2016) Malignant transformation of mature cystic teratoma of the ovary: 30year experience of a single tertiary care center. Eur J Gynaecol Oncol 37(6): 809-813

8. Niu D, Li Z, Sun L, Cao D (2018) Carcinoid Arising from the Teratomatous Bronchial Mucosa in a Mature Cystic Teratoma of the Ovary: A Case Report. Int J Gynecol Pathol 37(2):123-127.

9. Kim JY (2016) A carcinoid tumor arising from a mature cystic teratoma in a 25-year-old patient: a case study. World J Surg Oncol 14: 120.

10. Feng X, Xu L (2018) Rare case of squamous cell carcinoma arising in a recurrent ovarian mature cystic teratoma of a young woman: A case report and review of the literature. Medicine (Baltimore) 97(20): e10802.

11. Tosuner Z, Sönmez FC, Arici DS, Dansuk R (2015) Carcinoid tumor arising in a mature cystic teratoma: A case report. Oncol Lett 9(5): 2236-2238.
12. Ting WH, Hsiao SM, Lin HH, Wei MC (2014) Primary carcinoid tumor of the ovary arising in a mature cystic teratoma: a case report. Eur J Gynaecol Oncol 35(1): 100-102.

13. Petousis S, Kalogiannidis I, Margioula-Siarkou C, Traianos A, Miliaras D, et al. (2013) Mature ovarian teratoma with carcinoid tumor in a 28-year-old patient. Case Rep Obstet Gynecol 2013: 108582.

14. Lenicek T, Tomas D, Soljacić-Vranes H, Kraljević Z, Klarić P, et al. (2012) Strumal carcinoid of the ovary: report of two cases. Acta Clin Croat 51(4): 649-653.

15. Spaulding R, Alatassi H, Stewart MD, Moghadamfalahi M (2014) Ependymoma and carcinoid tumor associated with ovarian mature cystic teratoma in a patient with multiple endocrine neoplasia I. Case Rep Obstet Gynecol 2014: 712657.

\section{Your next submission with Juniper Publishers will reach you the below assets}

- Quality Editorial service

- Swift Peer Review

- Reprints availability

- E-prints Service

- Manuscript Podcast for convenient understanding

- Global attainment for your research

- Manuscript accessibility in different formats

( Pdf, E-pub, Full Text, Audio)

- Unceasing customer service

Track the below URL for one-step submission https://juniperpublishers.com/online-submission.php 